\title{
The Strategy Project: An Exploration of Enhancing Self-Regulated Learning in an Introductory Psychology Course
}

\author{
Valerie Whittlesey, $\mathrm{PhD}$ \\ Professor, Department of Psychological Science \\ Kennesaw State University
}

Hillary H. Steiner, PhD

\author{
Associate Director for the Scholarship of Teaching and Learning, Center for \\ Excellence in Teaching and Learning \\ Professor, Department of Psychological Science \\ Kennesaw State University
}

\begin{abstract}
College success requires development of self-regulated learning skills. This study describes a self-regulated learning strategy intervention in a large general education Introductory Psychology course, focusing on the second exam. Students' reflection responses across five time periods were compared with exam performance. Increased self-regulated learning strategies usage correlated with decreased passive learning strategies usage, increased hours of study, and increased academic performance. Strategy project interventions can be effective for introductory courses. However, because students may revert to passive strategies that worked in the past, strategy instruction should be extended throughout a course.
\end{abstract}

Many beginning students enter college expecting they will perform well, yet enter with the skills and mindset of high-school students (Balduf, 2009; Erickson \& Strommer, 2005; Pintrich, 2002; Weinstein et al., 2011) with misunderstandings about the way people learn (Bjork et al., 2013; Park et al., 2012). For college success, students must engage in higher-level learning, take ownership of their own learning, use the best resources and strategies for the task, and reflect on their own learning. In essence, they must enter college as self-regulated learners (Zimmerman, 2000).

Students entering college differ in the quality and quantity of their selfregulatory and metacognitive processes (Cohen, 2012; Geller et al., 2018; Kitsantas, 2002; Zimmerman, 2000). Self-regulators set clear and realistic goals, use strategies, self-monitor, evaluate their processes, and complete tasks on time with high levels of motivation. Many students enter college convinced they are prepared for college level work but quickly discover skill deficits. Many also believe they are using effective strategies despite contrary evidence (Bjork et al., 2013). These skill deficits are not limited to poor performing students. Although some high-achieving students use more effective strategies (Geller et al., 2018), high-achieving high school students can struggle when they reach college because of their misunderstandings about learning (Bjork et al., 2013) and their reluctance to relinquish the strategies that have worked for them for years (Balduf, 2009). Thus, self-regulated learning skills are important to teach all college students at all achievement levels.

Self-regulated learning and behaviors are predictors of academic learning success (Cohen, 2012; Dunlosky et al., 2013; Pintrich \& Degroot, 1990). High performing students are more accurate in self-assessments of their knowledge (Hacker et al., 2000), 
and low performing students often show overconfidence, resulting in inaccurate selfassessments of their knowledge (Cohen, 2012; Dang et al., 2018; Geller et al., 2018; Hartwig \& Dunlosky, 2012; Kitsantas, 2002). Those students who choose appropriate strategies are the ones who are most successful (Brown-Kramer, 2020), which is partially influenced by how the course instructor treats the strategy in class (Bartoszewski \& Gurung, 2015). Fortunately, self-regulated learning and metacognitive strategies can be taught successfully (Cohen, 2012; McCabe, 2011; Paris \& Paris, 2001), especially to first-year college students (Rosario et al., 2010; Tuckman \& Kennedy, 2011) in introductory college-level courses (Brown-Kramer, 2020).

The strategy project, which was conceptualized by Steiner (2016), is an assignment that focuses students on enhancing their self-regulated learning skills. The strategy project assumes that self-regulation is best learned in an authentic context that is meaningful to students (Simpson et al. 1997; Sternberg \& Martin, 1998) and is a multistep project requiring students to plan, monitor, and evaluate newly learned strategies as they prepare for an exam in a course. Students are directed to complete several activities that promote self-regulated learning, including creating a study plan, using metacognitive study strategies, and reflecting on exam performance. In Steiner's study the strategy project was implemented in five sections of a first-year seminar course where students selected another course in which they were enrolled for the project. Since students were in their first year of college, courses selected were introductory general education courses in the arts, business, humanities, health, mathematics, social sciences, and natural sciences. End-of-semester reflection papers indicated the project raised awareness of and encouraged the use of self-regulated learning and metacognitive strategies and increased self-reported test scores for the selected exam. The strategy project was then implemented in thirty-three sections of a first-year seminar course matched with control sections (Steiner et al., 2019). Again, students selected another general education course in which they were enrolled for the project. The strategy project increased use of self-regulation skills as measured by the Motivated Strategies for Learning Questionnaire (Pintrich et al., 1991) and self-reported use of metacognitive strategies for the treatment group.

The current study expands previous studies by adapting and implementing the strategy project in a large general education Introduction to Psychology course. The project was implemented in the course where students used it. Thus, rather than examining students' self-reported exam performance, we were able to assess whether use of self-regulated learning strategies impacted students' actual performance throughout the course. We hypothesized that as students increased use of active learning strategies, engaged in self-reflections of their learning, and increased their study hours, their exam performance would increase.

\section{Method}

\section{Participants}

This exploratory study examined the implementation of a strategy project in an Introductory to Psychology course at Kennesaw State University (KSU) during fall, 2019. KSU is a large public university near Atlanta, GA, and is a Carnegie-designated R2 institution. Class enrollment was 111 students. The course is one of seven courses 
required in KSU's social science general education core and is required of psychology majors and several other majors within the university. Mean age of participants was $18.4, S D=1.3$. The majority of students were female $(76.6 \%)$. Approximately half (51.4\%) were White, 29.7\% were Black/African American, 10.8\% were Hispanic/Latino, and other races/ethnicities $(8.1 \%)$ made up the remainder of students.

An Introductory to Psychology course at KSU during spring 2020 without the strategy project intervention served as the control group. The control group had a similar class enrollment and time of day; the teaching modality (face-to-face), instructor, and course materials were identical to the experimental group aside from the absence of the strategy project and exam wrappers.

\section{Procedures}

During the first week of class for both the experimental and control groups, the second author requested the consent of students enrolled in classes taught by the first author to participate in the study. Students were made aware that the study was approved by KSU's Institutional Review Board. The strategy project was explained to students in the experimental group. For exam 2, students would develop a study plan, use a variety of test preparation strategies to study for the exam, and complete written reflections of their learning and the experience. They understood that the strategy project assignments were expected of all students in the course and were designed to enhance learning and academic performance, but students who did not consent to participate would have their data excluded from further analysis. Students were told there would be five exams during the course, each containing 50 multiple-choice questions (assessing remembering, understanding, applying, and analyzing course material) worth 100 points, and that the strategy project was designed to improve their self-regulated learning and student performance in the course. The first four exams covered two chapters, and the fifth exam covered three chapters. The control group received the same exams 1, 2, and 3 (worth 100 points each). However, due to the unexpected pandemic-related conversion to remote instruction mid-semester, the control group did not receive exams 4 and 5; instead, they completed five online quizzes from the textbook.

During week four (immediately after exam 1) for the experimental group, the instructor used a class period to provide instruction on the strategy project and associated assignments, effective reading of the textbook and notetaking, metacognition, and self-regulated learning, all of which were connected to coverage of the memory (encoding, storage, retrieval, and improving of memory) and cognition (language, problem solving, decision making, and intelligence) chapters. In preparing for the second exam, students selected four metacognitive strategies with one of the first two required: 1) active reading of the textbook, 2) active notetaking, 3) flashcards, 4) concept maps, 5) study groups, 6) tutorial sessions, and 7) self-developed quizzes. Appendix A provides an outline of class coverage of the seven metacognitive strategies.

For weeks five and six, students completed a two-week strategy project plan of study for the second exam using the four selected strategies. The plan of study encouraged distributed practice of the material, a strategy that is more effective than 
massed practice (Dunlosky et al., 2013; Putnam et al., 2016). For week seven, students took the second exam. For week eight, students submitted electronic assignments to the instructor in the learning management system demonstrating that they followed their plan of study to prepare for the second exam. The plan of study and the electronic evidence assignments were each worth 75 points out of a semester total for the class of 1,000 points; the instructor allowed students one week to submit the work in the correct electronic formats for evaluation. During the remainder of the semester, the instructor encouraged students to continue using the metacognitive strategies though announcements during the class lectures. At the beginning of the class period after each exam, the instructor distributed graded exams back to students and reviewed and discussed exam questions and answers with the class. Students then completed a paper exam wrapper in class (see Appendix B), adapted from Lovett (2013) and Soicher and Gurung (2017). Exam wrapper questions asked students to reflect on their exam performance. This strategy increased response rates and immediacy of the selfreflections. Though the control group did not complete exam wrappers, the instructor distributed graded exams back to students and reviewed and discussed exam questions and answers with the class at the beginning of the class period after each exam.

Exam wrapper question 2 responses (study strategies used by students) were coded into categories by the first author (see Table 1). The second author then coded a random set of student responses $(11.2 \%)$ with all identifying information removed. Interrater reliability (a measure of agreement between two raters on the assignment of categories to a categorical variable) was $k=0.90, p<.009,95 \% \mathrm{CI}$ (confidence interval) $[0.95,0.85] ; k$ values of $0.80-1.00$ are considered almost perfect (Landis \& Koch, 1977). Participating in study groups and tutoring sessions were combined into one category because students conflated these categories. Exam wrapper question 3 (reflecting on exam errors) was not coded and analyzed since some percentages did not total to $100 \%$. Finally, exam wrapper question 4A (for exams 1-4: "Name three things you plan to do differently in preparing for the next exam") and question 4B (for exam 5: "In what ways have you used these strategies in other courses?") were analyzed qualitatively for recurring themes using thematic analysis (Braun \& Clarke, 2006; Nowell et al., 2017), a method which involves flexible and open coding that allow for themes to emerge. Analysis of wrapper question $4 \mathrm{~A}$ was completed by the first author and wrapper question $4 \mathrm{~B}$ was completed by the second author; however, both authors reviewed and agreed upon coding procedures and informally reviewed both sets of data. The results of this analysis are presented along with the quantitative data analysis below.

\section{Table 1}

\section{Coding of Students' Learning Strategies}

Active self-regulated learning strategies
- Active reading, annotating, or outlining of the textbook material 
Table 1 Cont.

Active self-regulated learning strategies

- Reorganizing, annotating, or summarizing class notes

- $\quad$ Developing and using one's own flashcards or using the textbook's flashcards

- Creating concept charts, diagrams, or concept maps

- $\quad$ Participating in study groups or tutoring sessions

- $\quad$ Developing and taking one's own quizzes or taking the textbook's quizzes

- $\quad$ Distributed studying

- $\quad$ Teaching material to oneself or to someone else

- Identifying and applying concepts and terms

- Asking questions in class about unclear material

Passive learning strategies

- Reading or rereading the textbook

- Taking notes in class, reading, or rereading class notes

- Watching videos of concepts found online

- $\quad$ Reading the textbook chapter review or summary

- $\quad$ Reading the study guide provided by the instructor

Note. These data were collected from the exam wrapper assignments and coded as either active or passive learning strategies.

\section{Exam Scores}

\section{Results}

First, for the experimental group, we wanted to determine if exam performance increased with the implementation of the strategy project intervention 
which occurred in preparation for exam 2, so a within-subjects ANOVA comparing students' scores on the five exams was performed. It revealed a significant effect, and the effect size (magnitude of the differences among the scores) was large, Wilks' Lambda $=.76, F(4,97)=7.50, p=.001, \eta_{p}{ }^{2}=.24$. Bonferroni post-hoc tests for multiple comparisons indicated which set of scores differed from one another. There was significantly higher performance for exam 2 compared to exams 1, 4, and 5; there was also significantly higher performance for exam 3 compared to exam 4 .

Second, we analyzed exam performance for the control group, which did not complete the strategy project and only completed the first three exams. A withinsubjects ANOVA (Wilks' Lambda $=.74, F(2,101)=17.83, p=.001, \eta_{p}{ }^{2}=.26$ ) on students' three exam scores was performed, and it revealed a significant effect and a large effect size. Bonferroni post-hoc tests indicated significantly higher performance for exam 1 compared to 2 and higher performance for exam 3 compared to 2. Table 2 shows the exam scores means and standard deviations for the experimental and control groups.

\section{Table 2}

Exam Scores Means and Standard Deviations for the Experimental and Control Groups

\begin{tabular}{llll}
\hline Measure & $M$ & $S D$ & $95 \% \mathrm{CI}$ \\
\hline Experimental Group & & & \\
Exam \#1 & $73.01_{\mathrm{af}}$ & 10.80 & {$[70.88,75.14]$} \\
Exam \#2 & $76.63 \mathrm{bc}$ & 12.06 & {$[74.25,79.01]$} \\
Exam \#3 & $74.40 \mathrm{bdf}$ & 12.21 & {$[71.99,76.81]$} \\
Exam \#4 & $69.50 \mathrm{ae}$ & 12.74 & {$[66.98,72.01]$} \\
Exam \#5 & $72.83 \mathrm{af}$ & 11.96 & {$[70.47,75.19]$} \\
Exam grade average & 73.27 & 9.32 & {$[71.19,74.90]$} \\
\hline Control Group & & & {$[70.82,75.04]$} \\
Exam \#1 & $72.93 \mathrm{a}$ & 10.80 & {$[71.66,77.34]$} \\
Exam \#2 & $67.88 \mathrm{~b}$ & 12.68 & 14.26 \\
Exam \#3 & $74.45 \mathrm{a}$ & $160.40,70.35]$ \\
\hline
\end{tabular}

Note. $\mathrm{N}=101$ for the experimental group and $\mathrm{N}=103$ for the control group. Scores with different subscripts differ at the $p=.01$ levels by Bonferroni post-hoc tests for multiple comparisons. $\mathrm{CI}=$ confidence level.

Third, we compared exam performance between the experimental group and the control group for exam 2 and for exam 3 using an independent-samples t-test. For exam 2, there was a significant difference and a moderate effect size $(t(210)=5.38, p<$ .001 , two tailed, $\left.\eta^{2}=.12\right)$ with higher scores for the experimental group $(M=76.63, S D$ $=12.06,95 \% \mathrm{CI}[74.31,79.05])$ than the control group $(M=67.88, S D=12.68,95 \% \mathrm{CI}$ [66.31, 68.39]); for exam 3, scores for the experimental $(M=74.40, S D=12.21)$ and control group $(M=74.45, S D=14.26)$ were not significantly different from each other. 
In summary, while scores for the experimental group increased, especially on exam 2, scores for the control group decreased from the first to the second exam.

\section{Active Self-Regulated Learning Strategies}

We were interested in examining the experimental group's choice of strategies, as well as the change in these choices over time. Table 3 presents the selfreported use of active self-regulated learning strategies for each exam and collapsed across all exams.

Table 3

Self-Reported Use of Active Self-Regulated Learning Strategies to Prepare for Exams

\begin{tabular}{|c|c|c|c|c|c|c|c|}
\hline Strategies & $\begin{array}{l}\text { Use of } \\
\text { strategy }\end{array}$ & $\begin{array}{l}\text { Exam } \\
\# 1 \\
\end{array}$ & $\begin{array}{l}\text { Exam } \\
\# 2 \\
\end{array}$ & $\begin{array}{l}\text { Exam } \\
\# 3 \\
\end{array}$ & $\begin{array}{l}\text { Exam } \\
\# 4\end{array}$ & $\begin{array}{l}\text { Exam } \\
\# 5\end{array}$ & $\begin{array}{l}\text { Total } \\
\text { Use }\end{array}$ \\
\hline $\begin{array}{l}\text { Active reading, } \\
\text { annotating, or outlining } \\
\text { of textbook material }\end{array}$ & $\begin{array}{l}\text { Yes } \\
\text { No }\end{array}$ & $\begin{array}{l}5 \\
86 a\end{array}$ & $\begin{array}{l}25 \\
62 \mathrm{~b}\end{array}$ & $\begin{array}{l}19 \\
65 b\end{array}$ & $\begin{array}{l}21 \\
63 b\end{array}$ & $\begin{array}{l}18 \\
74 \mathrm{~b}\end{array}$ & $\begin{array}{l}88 \\
350\end{array}$ \\
\hline $\begin{array}{l}\text { Reorganizing, } \\
\text { annotating, or } \\
\text { summarizing class notes }\end{array}$ & $\begin{array}{l}\text { Yes } \\
\text { No }\end{array}$ & $\begin{array}{l}12 \\
79 a\end{array}$ & $\begin{array}{l}39 \\
48 \mathrm{~b}\end{array}$ & $\begin{array}{l}14 \\
70 \mathrm{a}\end{array}$ & $\begin{array}{l}12 \\
72 \mathrm{a}\end{array}$ & $\begin{array}{l}16 \\
76 a\end{array}$ & $\begin{array}{l}93 \\
345\end{array}$ \\
\hline $\begin{array}{l}\text { Developing and using } \\
\text { own flashcards or using } \\
\text { textbook's flashcards }\end{array}$ & $\begin{array}{l}\text { Yes } \\
\text { No }\end{array}$ & $\begin{array}{l}25 \\
66 \text { a }\end{array}$ & $\begin{array}{l}67 \\
20 b\end{array}$ & $\begin{array}{l}28 \\
56 \text { a }\end{array}$ & $\begin{array}{l}31 \\
53 \text { a }\end{array}$ & $\begin{array}{l}27 \\
65 a\end{array}$ & $\begin{array}{l}178 \\
260\end{array}$ \\
\hline $\begin{array}{l}\text { Creating concept charts, } \\
\text { diagrams, or concept } \\
\text { maps }\end{array}$ & $\begin{array}{l}\text { Yes } \\
\text { No }\end{array}$ & $\begin{array}{l}0 \\
91 \text { a }\end{array}$ & $\begin{array}{l}21 \\
66 b\end{array}$ & $\begin{array}{l}2 \\
82 \text { a }\end{array}$ & $\begin{array}{l}2 \\
82 \text { a }\end{array}$ & $\begin{array}{l}3 \\
89 a\end{array}$ & $\begin{array}{l}28 \\
410\end{array}$ \\
\hline $\begin{array}{l}\text { Developing and taking } \\
\text { quizzes or taking } \\
\text { textbook quizzes }\end{array}$ & $\begin{array}{l}\text { Yes } \\
\text { No }\end{array}$ & $\begin{array}{l}40 \\
51 \text { a }\end{array}$ & $\begin{array}{l}59 \\
28 b\end{array}$ & $\begin{array}{l}34 \\
50 a\end{array}$ & $\begin{array}{l}36 \\
48 \mathrm{a}\end{array}$ & $\begin{array}{l}45 \\
47\end{array}$ & $\begin{array}{l}214 \\
224\end{array}$ \\
\hline $\begin{array}{l}\text { Participating in study } \\
\text { groups or tutoring } \\
\text { sessions }\end{array}$ & $\begin{array}{l}\text { Yes } \\
\text { No }\end{array}$ & $\begin{array}{l}5 \\
86 \text { a }\end{array}$ & $\begin{array}{l}28 \\
59 \mathrm{~b}\end{array}$ & $\begin{array}{l}13 \\
71\end{array}$ & $\begin{array}{l}16 \\
68\end{array}$ & $\begin{array}{l}15 \\
77 a\end{array}$ & $\begin{array}{l}77 \\
361\end{array}$ \\
\hline Distributed studying & $\begin{array}{l}\text { Yes } \\
\text { No }\end{array}$ & $\begin{array}{l}2 \\
89\end{array}$ & $\begin{array}{l}2 \\
85\end{array}$ & $\begin{array}{l}2 \\
82\end{array}$ & $\begin{array}{l}6 \\
78\end{array}$ & $\begin{array}{l}4 \\
88\end{array}$ & $\begin{array}{l}16 \\
422\end{array}$ \\
\hline $\begin{array}{l}\text { Teaching material to } \\
\text { oneself or someone else }\end{array}$ & $\begin{array}{l}\text { Yes } \\
\text { No }\end{array}$ & $\begin{array}{l}2 \\
89\end{array}$ & $\begin{array}{l}0 \\
87\end{array}$ & $\begin{array}{l}1 \\
83\end{array}$ & $\begin{array}{l}1 \\
83\end{array}$ & $\begin{array}{l}5 \\
87\end{array}$ & $\begin{array}{l}9 \\
429\end{array}$ \\
\hline $\begin{array}{l}\text { Identifying and applying } \\
\text { concepts and terms }\end{array}$ & $\begin{array}{l}\text { Yes } \\
\text { No }\end{array}$ & $\begin{array}{l}1 \\
90\end{array}$ & $\begin{array}{l}1 \\
86\end{array}$ & $\begin{array}{l}0 \\
84\end{array}$ & $\begin{array}{l}0 \\
84\end{array}$ & $\begin{array}{l}0 \\
92\end{array}$ & $\begin{array}{l}2 \\
436\end{array}$ \\
\hline $\begin{array}{l}\text { Asking questions in class } \\
\text { about unclear material }\end{array}$ & $\begin{array}{l}\text { Yes } \\
\text { No }\end{array}$ & $\begin{array}{l}0 \\
91\end{array}$ & $\begin{array}{l}0 \\
87\end{array}$ & $\begin{array}{l}0 \\
84\end{array}$ & $\begin{array}{l}0 \\
84\end{array}$ & $\begin{array}{l}0 \\
92\end{array}$ & $\begin{array}{l}0 \\
438\end{array}$ \\
\hline
\end{tabular}

Note. Numbers in this table reflect frequencies of reporting presence (yes) or absence (no) of strategy use. Frequencies with different subscripts differ at $p<.05$ level. 
The most frequently used active self-regulated learning strategies across all exams were flashcards $(n=178)$ and quizzes $(n=214)$. We also wanted to examine frequencies of the presence or absence of each active learning strategy on each exam. The data was categorical, so a Cochran's Q test was used. There were significant results for six strategies: 1) use of active reading, annotations, or outlines of the textbook $\left(\chi^{2}(4)=\right.$ $24.93, p<.001)$; 2) reorganizing, annotating, or summarizing class notes $\left(\chi^{2}(4)=36.07\right.$, p. <.001); 3) developing and using flashcards or using the textbook's flashcards $\left(\chi^{2}(4)\right.$ $=62.32, p<.001) ; 4)$ creating concept charts, diagrams, or concept maps $\left(\chi^{2}(4)=33.88\right.$, $p<.001)$; 5) developing and taking quizzes or taking the textbook's quizzes $\left(\chi^{2}(4)=\right.$ $19.39, p<.001)$; and 6) participating in study groups or tutoring sessions $\left(\chi^{2}(4)=28.40\right)$, $p<.001)$. Bonferroni post-hoc tests indicated which set of scores were different from each other. There were significantly more usages of active reading, annotations, or outlines of the textbook for exams 2, 3, 4, and 5 compared to exam 1; significantly more usages of reorganizing/annotating/summarizing class notes, flashcards, and concept charts/diagrams/maps for exam 2 compared to exams 1, 3, 4, and 5; significantly more usages of self-quizzing for exam 2 compared to exams 1, 3, and 4; and significantly more usages of participating in study group or tutoring sessions for exam 2 compared to exams 1 and 5 . In summary, after learning about and practicing effective strategies, students increased their use of those strategies; however, by the end of the semester some students had returned to prior low levels of active self-regulated learning strategy use.

\section{Passive Learning Strategies}

Table 4 presents the self-reported use of passive learning strategies for each exam and collapsed across all exams.

\section{Table 4}

Self-Reported Use of Passive Learning Strategies to Prepare for Exams

\begin{tabular}{llllllll}
\hline Strategies & $\begin{array}{l}\text { Use of } \\
\text { strategy }\end{array}$ & $\begin{array}{l}\text { Exam } \\
\# 1\end{array}$ & $\begin{array}{l}\text { Exam } \\
\# 2\end{array}$ & $\begin{array}{l}\text { Exam } \\
\# 3\end{array}$ & $\begin{array}{l}\text { Exam } \\
\# 4\end{array}$ & $\begin{array}{l}\text { Exam } \\
\# 5\end{array}$ & $\begin{array}{l}\text { Total } \\
\text { Use }\end{array}$ \\
\hline $\begin{array}{l}\text { Taking notes in class or reading } \\
\text { or rereading class notes }\end{array}$ & Yes & 63 & 32 & 48 & 46 & 56 & 245 \\
& No & $30 \mathrm{a}$ & $55 \mathrm{~b}$ & 38 & 38 & $36 \mathrm{a}$ & 197 \\
& & & & & & & \\
Reading the study guide & Yes & 28 & 5 & 14 & 13 & 25 & 85 \\
provided by the instructor & No & $63 \mathrm{a}$ & $82 \mathrm{~b}$ & 70 & 71 & $67 \mathrm{a}$ & 353 \\
$\begin{array}{l}\text { Reading the textbook chapter } \\
\text { review or summary }\end{array}$ & Yes & 5 & 0 & 0 & 3 & 7 & 15 \\
No & $86 \mathrm{a}$ & $87 \mathrm{~b}$ & $84 \mathrm{~b}$ & 81 & 85 & 423 \\
Reading or rereading the & Yes & 43 & 27 & 35 & 28 & 46 & 179 \\
textbook & No & 48 & 60 & 49 & 56 & 46 & 259 \\
Watching videos of concepts & Yes & 6 & 3 & 2 & 3 & 2 & 16 \\
& No & 85 & 84 & 82 & 81 & 90 & 422 \\
\hline
\end{tabular}

Note. Numbers in this table reflect frequencies of reporting presence (yes) or absence (no) of strategy use. Frequencies with different subscripts differ at $p<.05$ (significant) and $p<.07$ (marginally significant) levels. 
The most frequently used passive learning strategies across all exams were taking/reading/rereading class notes $(n=245)$ and simple reading/rereading of the textbook $(n=179)$. Again, we examined frequencies of the presence or absence of each passive learning strategy on each exam using a Cochran's $Q$ test. There were significant or marginally significant results for three strategies: 1 ) notetaking in class, reading, or rereading class notes $\left(\chi^{2}(4)=15,38, p<.004\right)$; 2$)$ reading the textbook chapter review or summary $\left(\chi^{2}(4)=10.59, p=.032\right)$; and 3$)$ reading the study guide provided by the instructor $\left(\chi^{2}(4)=16.63, p<.002\right)$. Bonferroni post-hoc tests indicated significantly more uses of taking notes in class/reading/rereading class notes and for reading the study guide provided by the instructor for exams 1 and 5 compared to exam 2 . There were marginally more uses of reading the textbook chapter review or summary for exam 1 compared to exams 2 and 3. Thus, immediately after exposure and practice of active self-regulated learning strategies, students' use of less effective strategies decreased.

\section{Student Reflections on their Study Habits}

For the first four exams, the final question on the exam wrapper was an openended question asking students to list three things they planned to do differently in preparation for the next exam. This question was designed to encourage strategy planning based on the experience of the current exam. While many students listed active, self-regulated learning strategies such as self-quizzing, appropriate use of flashcards, and teaching the content to others on the very first exam wrapper, they also mentioned time-consuming passive learning strategies such as rereading the textbook and rewriting notes. As the strategy project intervention was introduced, students mentioned fewer passive learning strategies and became more specific in their descriptions of the more frequent active strategies they listed. For example, rather than simply listing "flashcards" as on exam wrapper 1, in later exam wrappers they indicated, for example, they would "change the way I do flashcards and go over the things I struggle with more." In later exam wrappers, many also listed goals to create a supportive learning environment, including changes of environment to reduce distraction and more advance planning, "[using] methods from the strategy project" as a guide. Perhaps most striking was the increase during the semester of references to distributed practice, an idea that was rarely mentioned on the first exam wrapper. Beginning with exam wrapper 2, many students detailed their plans for spreading out their studying in a pre-determined schedule (e.g., "studying for at least 20 minutes for the next exam on the days we have class"), a strategy that was encouraged during the project.

The final question on the last exam wrapper asked students to reflect on what ways they have used the strategies learned from the project in other courses. Many of the students made general statements about how the strategies helped them learn in all their courses (e.g., "I have learned so much about the way I learn and how to study best... I will carry that through college."), but others mentioned applying the strategies to specific courses, including art, religion, history, economics, government, communication, math, Spanish, chemistry, and exercise science. For example, one student outlined what strategies applied to her particular courses: "I use flashcards in human communication; active notetaking helped in US History; active reading helped 
in art." By far the most common strategies mentioned were active reading and notetaking, flashcards, and quizzing. And as with exam wrappers 2-4, many mentioned the importance of creating a study plan for distributed practice, despite the challenge of doing so: "Spreading out my time has been a difficult task that I need to work on."

\section{Hours Studied}

Exam wrapper question 1 asked students to report how much time they spent preparing for this exam. Hours studied for each of the five exams was on a continuous scale, so a within-subjects ANOVA was performed. It revealed a significant effect, and the effect size was large, Wilks' Lambda $=.53, F(4,59)=13.19, p<.001, \eta_{\mathrm{p}}{ }^{2}=.47$ (see table 5). Bonferroni post-hoc tests indicated which set of scores differed from one another. There was a significantly lower number of hours studied for exam 1 compared to exams 2, 3, 4, and 5, and significantly lower number of hours studied for exam 4 compared to exams 2 and 5 . Table 5 shows the means and standard deviations for hours studied for each exam.

\section{Table 5}

Exam Scores Means and Standard Deviations for Hours Studied for Five Exams

\begin{tabular}{llll}
\hline Measure & $M$ & $S D$ & $95 \% \mathrm{CI}$ \\
\hline Exam \#1 hours studied & $3.37 \mathrm{ac}$ & 2.15 & {$[2.82,3.91]$} \\
Exam \#2 hours studied & $5.89 \mathrm{~b}$ & 3.47 & {$[5.02,6.76]$} \\
Exam \#3 hours studied & $5.07 \mathrm{bd}$ & 4.07 & {$[4.05,6.10]$} \\
Exam \#4 hours studied & $4.46 \mathrm{~d}$ & 2.72 & {$[3.77,5.14]$} \\
Exam \#5 hours studied & $6.33 \mathrm{~b}$ & 4.77 & {$[5.13,7.54]$} \\
Average hours studied & 5.02 & 3.72 & {$[4.00,6.08]$} \\
\hline
\end{tabular}

Note. These exam wrapper data are self-reported number of hours studied for exams $(\mathrm{N}=63)$. Scores with different subscripts differ at the $p=.05$ levels by Bonferroni posthoc tests for multiple comparisons. $\mathrm{CI}=$ confidence level.

\section{Summary}

Participant's total use of active self-regulated learning strategies $(M=8.02, S D$ $=3.88, n=64)$ and participant's use of passive learning strategies $(M=6.66, S D=2.84$, $n=64)$ were calculated. Exam scores $(M=73.27, S D=9.33, n=103)$ and hours studied $(M=5.02, S D=3.72, n=103)$ were averaged. A Pearson product moment correlation coefficient was performed to describe the strength and direction of the relationship for these continuous variables. There was a strong, negative relationship between use of active self-regulated and passive learning strategies $(r(62)=-.53, p<.001,95 \%$ CI [-.68, -.32]); as use of active learning strategies increased, use of passive learning strategies decreased. There was a moderate, positive relationship between use of active learning 
strategies and students' average exam scores $(r(62)=+.33, p<.001,95 \% \mathrm{CI}[0.10,0.54])$; as active learning strategies increased, exam scores increased. There was a moderate, positive relationship between average number of hours studied and students' average exam scores $(r(61)=+.33, p<.001,95 \%$ CI $[0.09,0.53])$; as number of hours studied increased, exam scores increased. Use of active learning strategies and number of hours studied accounted for $22 \%$ of the variance in students' exam scores.

\section{Discussion}

Study findings indicate the strategy project positively impacted students' use of metacognitive and self-regulated learning strategies and exam performance; however, some of the positive impact seemed to be temporary. For the experimental group, the strategy project was implemented before the second exam, allowing students to connect the strategies to evidence-based instruction on their effectiveness. It is important to note that course material became more difficult after the introductory chapters of exam 1, so the students' performance increase after exam 1 may be even more impressive. Students in the experimental group began to use effective strategies on exam 2 not used on the first exam and indicated they planned to do so on exam wrapper 1, perhaps prompted by the exam wrapper itself. As time went on, plans for using appropriate strategies became more frequent and detailed on the exam wrappers.

There were also higher scores on exam 2 than 4 and 5, but exam score 4 was lower than exam 3. For exam 2, students had to submit graded assignments that demonstrated they were using the self-regulated learning strategies from the project. Therefore, although students indicated their intent to use good strategies on subsequent exam wrappers, students seemed to use the strategies on exams 2 and 3. Despite the better academic performance that was tied to the strategy project, and although they indicated their intent to use good strategies in wrapper 3, students may have gradually slipped back to old patterns by exam 4 of not studying actively, especially as demands on their time increased without the graded incentives to continue using the active learning strategies. Also, the chapters associated with exam 4 were short, and some students indicated that exam came quicker than they realized. For the control group, exam 2 scores were lower than exams 1 and 3. The experimental group had higher scores than the control group for exam 2 as expected. Unexpectedly, there was no difference in the exam 3 scores for the two groups. The increased performance on exam 3 for the control group is difficult to explain, but the timing of the exam for this group (March 5) corresponded with increases in COVID cases and uncertainty around the rest of the semester.

In the experimental group, students studied fewer hours on exam 1 compared to exams 2, 3, 4, and 5. Thibodeaux et al. (2017) found students plan and actually spend less time on academics versus socializing and work obligations in their first semester of college, despite the higher academic expectations and demands of college. By second semester in Thibodeax's study, time spent on obligations was still higher than time spent on academics, but academic time use (planned and actual academic hours) related to higher self-regulated learning and higher academic performance. In our own study, we found students increased their study hours in the two exams following the 
strategy project intervention, temporarily decreased them for exam 4, then increased them again for the last exam. This again may be due to exam 4 sneaking up on students.

Students used little active textbook reading on the first exam, but increased its use for exams 2, 3, 4, and 5 with the implementation of the strategy project. Simpson and Nist (1990), Simpson et al. (2004), Nash-Ditzel (2010), and Putnam et al. (2016) point out that active reading and the practice of textbook annotations encourages elaborative interrogation, paraphrasing, and deep learning. Self-regulated learning also applies to social behavior such as using academic support services and seeking help from the instructor (Zimmerman, 2008). Students did not participate in study groups or attend tutorial sessions for the first exam but increased participation for exam 2 with a decline on exam 5. Flashcards and quizzes had a high usage compared to other active learning strategies; Miyatsu et al. (2018) reported flashcards is a popular study strategy for students. We suspect that the focus on developing quizzes for the strategy project and the textbook quizzes that were available for students led to the high quiz usage in this study. Students further increased their use of flashcards and quizzes for exam 2 but declined to original levels by exam 5 . The intervention also led to greater use of active notetaking and creating concept charts/diagrams/maps for exam 2 with a decline by exam 5. Research pointed to the effectiveness of flashcards and self-testing for promoting engagement with material (Dunlosky et al., 2013; Putnam et al., 2016; Rodriguez et al., 2018; Senzaki et al., 2017) and active notetaking for promoting organization, self-quizzing, and reflection (Dunlosky et al., 2013; Putnam et al., 2016). The data points to the need for students to continue using these active learning strategies.

Simply taking, reading, or rereading class notes and reading or rereading of the textbook (without deep processing) were passive strategies with high levels of usage, a finding substantiated by Miyatsu et al. (2018). Students in our study decreased use of taking, reading, or rereading class notes and reviewing the study guide provided by the instructor for exam 2 compared to exam 1 but increased by exam 5 . Dembo and Seli (2004) and McDaniel and Einstein (2020) pointed out that despite negative feedback and poor grades, many students are reluctant to change their learning strategies because they are unable to appropriately judge whether they are learning and/or overconfidence in their knowledge (Cohen, 2012; Dang, 2018; Geller et al., 2018; Hartwig \& Dunlosky, 2012; Kitsantas, 2002). Unfortunately, many students "often find themselves making study decisions by triage instead of trying to maximize long-term learning" (Kornell \& Bjork, 2007, p. 223), and this may be even more true at the end of the semester when students are overburdened and ready for a break. Thus, the interventions introduced in this course should not be promoted as one-time events but skills to be developed over time as students integrate the phases of the self-regulatory cycle with their learning activities.

As predicted, as students used more active learning strategies, they used fewer passive learning strategies. This observation was exhibited in their planning and reflection on open-ended exam wrapper questions as well. As students used more active learning strategies and as their number of hours studied increased, they scored higher on exams. On the last exam wrapper, students reported applying these strategies to other courses, many of them matching specific strategies to specific courses. This was encouraging, as one of the goals of this project was to encourage 
metacognitive reflection about the use of specific strategies for specific tasks. The strategy project may be a worthwhile assignment for introductory or general education courses if it is adapted to specific course goals, outcomes, and content. In the Steiner (2016) and Steiner et al. (2019) studies, students implemented the strategy project in a general education course in a variety of disciplines; completing practice problems was an active learning strategy option for those students who selected a mathematics-based course for the project. Elaborative interrogation and self-explanation are also active learning strategies demonstrated to be effective in a variety of disciplines (Dunlosky et al., 2013). Elaborative interrogation involves asking "why" questions as one is learning factual information. Self-explanation involves integrating new information with prior knowledge. Data has shown the use of elaborative interrogation and self-explanation is related to higher academic performance in a variety of courses, for example, computer science (Gurung et al., 2020).

There are limitations to our study that necessitate caution in interpreting the findings. First, the experimental group data was collected in fall, 2019, and the control group data was collected in spring, 2020. Though all aspects of the course aside from the intervention were virtually the same, student populations in the course may differ by semester. Additionally, the COVID-19-related transition to remote instruction

...as self-regulation is not a onetime transformation but a collection of skills developed over time, we also recommend that instructors ...promote its use throughout the course so that students do not return to old learning habits. occurred during the middle of spring semester for the control group, so exams 4 and 5 were not given. The strategy project was implemented for exam 2 for the experimental group, so we were able to compare performance on exams 2 and 3 between the two groups. Future studies should examine several full semesters of data.

Additionally, the strategy project required students to develop their own flashcards and self-developed quizzes for exam 2 as graded assignments. If students' exam wrappers indicated they used flashcards and quizzes as a study strategy for the other exams, it was not clear if they were the textbook's, self-developed, or some combination of the two. This response was coded as an active strategy, but this distinction should be addressed in future studies.

In conclusion, as with previous studies (Steiner, 2016; Steiner et al., 2019), the strategy project had some positive impacts on student's use of self-regulated learning strategies and on student performance, and therefore, we recommend instructors use an authentic, embedded assignment like the strategy project, perhaps as a companion to instruction on cognitive principles. However, as self-regulation is not a one-time transformation but a collection of skills developed over time, we also recommend that instructors find ways with graded assignments to promote its use throughout the course so that students do not return to old learning habits.

\section{References}

Balduf, M. (2009). Underachievement among college students. Journal of Advanced Academics, 20(2), 274-294. https://doi.org/10.1177\%2F1932202X0902000204 
Bartoszewski, B. L., \& Gurung, R. A. (2015). Comparing the relationship of learning techniques and exam score. Scholarship of Teaching and Learning in Psychology, 1(3), 219-228. https://doi.org/10.1037/stl0000036

Bjork, R. A., Dunlosky, J., \& Kornell, N. (2013). Self-regulated learning: Beliefs, techniques, and illusions. Annual Review of Psychology, 64, 417-444. https://doi.org/10.1146/annurev-psych-113011-143823

Braun, V., \& Clarke, V. (2006). Using thematic analysis in psychology. Qualitative Research in Psychology, 3(2), 77-101.

Brown-Kramer, C. R. (2020). Improving students' study habits and course performance with a "learning how to learn" assignment. Teaching of Psychology. https://doi.org/10.1177/0098628320959926

Cohen, M. T. (2012). The importance of self-regulation for college student learning. College Student Journal, 46(4), 892-903.

Dang, N. V., Chiang, J. C., Brown, H. M., \& McDonald, K. K. (2018). Curricular activities that promote metacognitive skills impact lower-performing students in an introductory biology course. Journal of Microbiology and Biology Education, 19(1), 1-8. https://doi.org/10.1128/jmbe.v19i1.1324

Dembo, H. M., \& Seli, H. P. (2004). Students' resistance to change in learning strategies courses. Journal of Developmental Education, 27(3), 2-11.

Dunlosky, J., Rawson, K. A., Marsh, E. J., Nathan, M. J., \& Willingham, D. T. (2013). Improving students' learning with effective learning techniques: Promising directions from cognitive and educational psychology. Psychological Science in the Public Interest, 14(1), 4-58.

Erickson, B. L., \& Strommer, D. W. (2005). Inside the first-year classroom. Challenges and constraints. In M. L. Upcraft, J. N. Gardner, \& B. O. Barefoot (Eds.), Challenging and supporting the first-year student. A handbook for improving the first year of college (pp. 241-256). Wiley.

Geller, J., Toftness, A. R., Armstrong, P. I., Carpenter, S. K., Manz, C. L., Coffman, C. R., \& Lamm, M. H. (2018). Study strategies and beliefs about learning as a function of academic achievement and achievement goals. Memory, 26(5), 683-690. https://doi.org/10.1080/09658211.2017.1397175

Gurung, R. A., Mai, T., Nelson, M., \& Pruitt, S. (2020). Predicting learning: Comparing study techniques, perseverance, and metacognitive skill. Teaching of Psychology, 47(4), 1-7. https://doi.org/10.1177\%2F0098628320972332

Hacker, D. J., Bol, L., Horgan, D. D., \& Rakow, E. A. (2000). Test prediction and performance in a classroom context. Journal of Educational Psychology, 92, 160170. https://psycnet.apa.org/doi/10.1037/0022-0663.92.1.160

Hartwick, M. K. \& Dunlosky, J. (2012). Study strategies on college students: Are selftesting and scheduling related to achievement? Psychonomic Bulletin E Review, 19(1), 126-134.

Kitsantas, A. (2002). Test preparation and test performance: A self-regulatory analysis. Journal of Experimental Education, 41, 231-240. https://doi.org/10.1080/00220970209599501

Kornell N., \& Bjork, R. A. (2007). The promise and perils of self-regulated study. Psychonomic Bulletin E Review, 14(2), 219-224. 
Landis, J. R., \& Koch, G. G. (1977). The measurement of observer agreement for categorical data. Biometrics, 33, 159-174.

Lovett, M. C. (2013). Make exams worth more than the grade: Using exam wrappers to promote metacognition. In M. Kaplan, N. Silver, D. LaVague-Manty, \& D. Meizlish (Eds.), Using reflection and metacognition to improve student learning: Across the disciplines, across the academy (pp. 18-52). Stylus.

McCabe, J. (2011). Metacognitive awareness of learning strategies in undergraduates. Memory \& Cognition, 39, 462-476. https://doi.org/10.3758/s13421-010-0035-2

McDaniel, M., \& Einstein, G. (2020). Training learning strategies to promote selfregulation and transfer: The knowledge, belief, commitment, and planning framework. Perspectives on Psychological Science, 15(6), 1363-1381. https://doi.org/10.1177\%2F1745691620920723

Miyatsu, T., Nguyen, K., \& McDaniel, M. (2018). Five popular study strategies: Their pitfalls and their optimal implementation. Perspectives on Psychological Science, 13(3), 390-407. https://doi.org/10.1177\%2F1745691617710510

Nash-Ditzel, S. (2010). Metacognitive reading strategies can improve self-regulation. Journal of College Reading and Learning, 40(2), 45-63. https://doi.org/10.1080/10790195.2010.10850330

Nowell, L. S., Norris, J. M., White, D. E., \& Moules, N. J. (2017). Thematic analysis: Striving to meet the trustworthiness criteria. International Journal of Qualitative Methods, 16(1), 1-13. https://doi.org/1609406917733847

Park C., Edmonson, D., \& Lee, J. (2012). Development of self-regulation abilities as predictors of psychological adjustment across the first year of college. Journal of Adult Development, 19(1), 40-49. https://doi.org/10.1007/s10804-011-9133-z

Paris, S. G., \& Paris, A. H. (2001). Classroom applications of research on self-regulated learning. Educational Psychologist, 36, 89-101. https://doi.org/10.1207/S15326985EP3602 4

Pintrich, P. R. (2002). The role of metacognitive knowledge in learning, teaching, and assessing. Theory into Practice, 41(4), 219-225. https://doi.org/10.1207/s15430421tip4104_3

Pintrich, P. R., \& DeGroot, E. V. (1990). Motivational and self-regulated learning components of classroom academic performance. Journal of Educational Psychology, 82(1), 33-40. https://doi.org/10.1037/0022-0663.82.1.33

Pintrich, P. R., Smith, D. A. F., García, T., \& McKeachie, W. J. (1991). A manual for the use of the motivated strategies questionnaire (MSLQ). Ann Arbor, MI: University of Michigan, National Center for Research to Improve Postsecondary Teaching and Learning.

Putnam, A., Sungkhasettee, \& Roediger, H. (2016). Optimizing learning in college: Tips from cognitive psychology. Perspectives on Psychological Science, 11(5), 652-660. https://doi.org/10.1177\%2F1745691616645770

Rodriguez, F., Kataoka, S., Rivas, M.J., Kadandale, P., Nili, A., \& Warschauer. (2018). Do spacing and self-testing predict learning outcomes? Active Learning in Higher Education, 1-15. https://doi.org/10.1177/1469787418774185

Rosario, P., Nunez, J. C., Gonzalez-Pienda J., Valle, A., Trigo, L., \& Guimaraes, C. (2010). Enhancing self-regulation and approaches to learning in first-year 
college students: A narrative-based programme assessed in the Iberian Peninsula. European Journal of Psychology of Education, 25(4), 411-428.

Senzaki, S., Hackathorn, J., Appleby, D., \& Gurung, R. (2017). Reinventing flashcards to increase student learning. Psychology Learning and Teaching, 16(3), 353-368. https://doi.org/10.1177/1475725717719771

Simpson, M. L., Hynd, C. R., Nist, S. L., \& Burrell, K. I. (1997). College academic assistance programs and practices. Educational Psychological Review, 9(1), 3971.

Simpson, M. L., \& Nist, S. L. (1990). Textbook annotation: An effective and efficient study strategy for college students. Journal of Reading, 34, 122-129.

Simpson, M. L., Stahl, N. A., \& Francis, M. A. (2004). Reading and learning strategies: Recommendations for the 21st century. Journal of Developmental Education, 28(2), 2-14.

Soicher, R. N., \& Gurung, A. R. (2017). Do exam wrappers increase metacognition and performance? Psychology Learning E Teaching, 16(1), 64-73.

https://doi.org/10.1177\%2F1475725716661872

Steiner, H. H. (2016). The strategy project: Promoting self-regulated learning through an authentic assignment. International Journal of Teaching and Learning in Higher Education, 28(2), 271-282.

Steiner, H. H., Trivedi, N., \& Brown, J. (2019). Bringing a learning strategies project to scale in a first-year seminar. Journal of Effective Teaching in Higher Education, 1(2), 27-44.

Sternberg, R. A., \& Martin, M. (1988). When teaching thinking does not work: What goes wrong? Teachers College Record, 89(4), 555-578.

Thibodeaux, J., Deutsch, A., Kitsantas, A., \& Winsler, A. (2017). First-year college students' time use: Relations with self-regulation and GPA. Journal of Advanced Academics, 28(1), 5-27. https://doi.org/10.1177\%2F1932202X16676860

Tuckman B. W., \& Kennedy, G. J. (2011). Teaching learning strategies to increase success for first-term college students. The Journal of Experimental Education, 79, 478-504. https://doi.org/10.1080/00220973.2010.512318

Weinstein, C. E., Acee, T. W., \& Jung, J. (2011). Self-regulation of learning strategies. New Directions for Teaching and Learning, 126, 45-53. https://doi.org/10.1002/tl.443

Zimmerman, B. J. (2008). Investigating self-regulation and motivation: Historical background, methodological developments, and future prospects. American Educational Research Journal, 45, 166-183. https://doi.org/10.3102\%2F0002831207312909

Zimmerman, B. J. (2000). Attaining self-regulation: A social cognitive perspective. In M. Boekaerts, P. R. Pintrich, \& M. Zeidner (Eds.), Handbook of self-regulation (pp. 13-39). Academic Press. 


\section{Appendix A}

\section{Outline of Class Coverage of the Seven Metacognitive Strategies}

\section{Active Reading of the Textbook}

Preview the chapter

- Read and chapter headings, learning objectives, tables, graphs, and charts and think of questions you have about material

- Consider what is said in class

- $\quad$ Read and the chapter summary and any questions at the end of the chapter and think of questions you have about material

Reading of the chapter

- Thoroughly and actively read the material in its entirety

- Annotate the textbook and/or take notes

- Locate the topic sentence in each paragraph

- Locate key terms in the reading

- Ask questions that make you think about the material

- Connect the material to what you already know

- Review the examples provided to illustrate key concepts and think of your own examples

- Closely examine footnotes, tables, charts, diagrams, and other illustrations

2. Active Notetaking in Class (Using the Cornell Method)

- After each class, summarize your notes by taking out a sheet of paper

- Middle of the paper: Summarize your notes in paragraph form with general ideas

- Left side of the paper: Note key words and questions that you have

- Bottom of the paper: Provide a summary of your summary of your notes

\section{Use of Flashcards}

First set of cards

- Develop your own flashcards by writing the name of the concept on the front of each card

- Write the definition of the concept on the back of the card

Second set of cards

- Again, develop your own flashcards by writing the name of the concept on the front of each card

- This time, provide an example of the concept, indicate how you would teach the concept to someone else, or indicate how the concept is useful in your life on the back of the card 
Both sets of cards

- $\quad$ Select cards from each stack of cards

- Use the concept on the front of the card to see if you can provide definitions, applications, elaborations from the back of the card without looking

4. Use of Concept or Mind Maps

- Write the central concept in the middle or top of the page

- Use lines to connect main ideas to the central concept

- Add branches off the main points to add detail

- Use images and color, if possible, and consistent coding

5. Use of Study Groups

- Introduce yourselves to your classmates sitting next to you, if you have not already done so

- Exchange email addresses and set up days and times to study together for the exam

6. Use of Tutorial Sessions

- The Department of Psychological Science holds tutoring session for this course

- Tutors are undergraduate students who have taken this course and you can schedule a tutoring session(s) to assist you in the course

\section{Use of Self-Developed Quizzes}

- Create your own multiple-choice test using your textbook and class notes

- After your active reading of the textbook and/or active notetaking in class, answer your self-developed quiz questions without using the textbook or your class notes

- Use the textbook and your notes to grade yourself

- Focus on the questions you got wrong, analyzing where you went wrong and reaching out to me to clarify any issues 


\section{Appendix B}

\section{Exam Wrapper Questions}

1) Approximately how much time did you spend preparing for this exam? Please give a best estimate in hours, do not use ranges (e.g., 3.5, not 3-4)

2) What strategies did you use preparing for this exam?

3) After looking over your exam, estimate the percentage of points you lost due to each of the following (make sure the percentages total to $100 \%$ )

- Lack of understanding of the concept $\%$

- Not understanding what the question was asking __ $\%$

- Careless mistakes $\%$

- Not being able to apply concepts in new contexts $\%$

- Not recognizing that information or ideas were important $\%$

- $\quad$ Other (please specify): $\%$

4) A) (Exams 1-4): Based on your responses, name at least three things you plan to do differently in preparing for the next exam.

B) (Exam 5): In what ways have you used these strategies in other courses?

Valerie Whittlesey, PhD is Professor in the Department of Psychological Science at Kennesaw State University. She served in administrative roles at KSU (Associate and Assistant Vice President for Academic Affairs and Department Chair). She returned to full-time teaching in 2018 because of her love for teaching. Dr. Whittlesey is a Fellow for the Society for the Teaching of Psychology of the American Psychological Association. Current research interests are metacognitive learning and academic performance of college students, and she currently teaches the introduction to psychology course. Prior research interests include children's social and conceptual development and diversity in the psychology curriculum.

Hillary H. Steiner, PhD is Associate Director for SoTL at the Center for Excellence in Teaching and Learning and Professor in the Department of Psychological Science at Kennesaw State University. She has a lifelong passion for applying research on the science of learning to the classroom, and currently teaches courses in educational psychology at KSU. Her current research interests include metacognition, self-regulated learning, and SoTL support and advocacy in higher education. She is active in SoTL organizations from the local to international level, and is a recent recipient of the University System of Georgia Board of Regents' SoTL Award. 